\title{
Recent advances in mast cell activation and regulation
}

\section{[version 1; peer review: 2 approved]}

\author{
Hwan Soo Kim (1D1,2, Yu Kawakami1 , Kazumi Kasakura1, Toshiaki Kawakami (D1,3 \\ ${ }^{1}$ Laboratory of Allergic Diseases, Center for Autoimmunity and Inflammation, La Jolla Institute for Immunology, La Jolla, California, \\ 92037, USA \\ ${ }^{2}$ Department of Pediatrics, College of Medicine, The Catholic University of Korea, Seoul, South Korea \\ ${ }^{3}$ Department of Dermatlogy, University of California San Diego, School of Medicine, La Jolla, CA, 92093, USA
}

V1 First published: 19 Mar 2020, 9(F1000 Faculty Rev):196

https://doi.org/10.12688/f1000research.22037.1

Latest published: 19 Mar 2020, 9(F1000 Faculty Rev):196

https://doi.org/10.12688/f1000research.22037.1

\section{Abstract}

Mast cells are innate immune cells that intersect with the adaptive immunity and play a crucial role in the initiation of allergic reactions and the host defense against certain parasites and venoms. When activated in an allergen- and immunoglobulin $\mathrm{E}$ (IgE)-dependent manner, these cells secrete a large variety of allergenic mediators that are pre-stored in secretory granules or de novo-synthesized. Traditionally, studies have predominantly focused on understanding this mechanism of mast cell activation and regulation. Along this line of study, recent studies have shed light on what structural features are required for allergens and how IgE, particularly anaphylactic IgE, is produced. However, the last few years have seen a flurry of new studies on IgE-independent mast cell activation, particularly via Mrgprb2 (mouse) and MRGPRX2 (human). These studies have greatly advanced our understanding of how mast cells exert nonhistaminergic itch, pain, and drug-induced pseudoallergy by interacting with sensory neurons. Recent studies have also characterized mast cell activation and regulation by interleukin-33 (IL33) and other cytokines and by non-coding RNAs. These newly identified mechanisms for mast cell activation and regulation will further stimulate the allergy/immunology community to develop novel therapeutic strategies for treatment of allergic and non-allergic diseases.

Keywords

Allergy, mast cells, allergen, IgE, FceRI, MRGPRX2, IL-33, miRNA

\section{Open Peer Review}

Approval Status

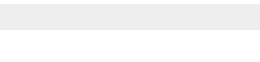

1

2

version 1

19 Mar 2020

Faculty Reviews are review articles written by the prestigious Members of Faculty Opinions. The articles are commissioned and peer reviewed before publication to ensure that the final, published version is comprehensive and accessible. The reviewers who approved the final version are listed with their names and affiliations.

1. Jiro Kitaura, Juntendo University, Tokyo, Japan

2. Cem Akin, University of Michigan, Ann Arbor, USA

Any comments on the article can be found at the end of the article. 
Corresponding author: Toshiaki Kawakami (toshi@lji.org)

Author roles: Kim HS: Writing - Original Draft Preparation, Writing - Review \& Editing; Kawakami Y: Writing - Review \& Editing; Kasakura K: Writing - Review \& Editing; Kawakami T: Conceptualization, Funding Acquisition, Investigation, Supervision, Writing Original Draft Preparation, Writing - Review \& Editing

Competing interests: Cem Akin has a consultancy agreement with Blueprint Medicines from which he receives research funding.

Grant information: Work in the authors' laboratory is supported in part by National Institutes of Health (NIH) grant R01 AI146042 and Kyowa Kirin Pharmaceutical Research. YK is supported by NIH training grant T32 AI125179.

The funders had no role in study design, data collection and analysis, decision to publish, or preparation of the manuscript.

Copyright: ( $) 2020 \mathrm{Kim}$ HS et al. This is an open access article distributed under the terms of the Creative Commons Attribution License, which permits unrestricted use, distribution, and reproduction in any medium, provided the original work is properly cited.

How to cite this article: Kim HS, Kawakami Y, Kasakura K and Kawakami T. Recent advances in mast cell activation and regulation [version 1; peer review: 2 approved] F1000Research 2020, 9(F1000 Faculty Rev):196 https://doi.org/10.12688/f1000research.22037.1

First published: 19 Mar 2020, 9(F1000 Faculty Rev):196 https://doi.org/10.12688/f1000research.22037.1 


\section{Introduction}

Mast cells (MCs) play a crucial role in allergic reactions and the host defense against certain parasites, bacteria, and venoms. Morphologically, MCs are featured by a large number of secretory granules containing various bioactive molecules, including histamine, serotonin, proteoglycans, and proteases. Upon encounter with multivalent antigen (or allergen), antigen-specific immunoglobulin E (IgE)-bound high-affinity IgE receptors (FceRI) on the surface of MCs are cross-linked or aggregated. Consequently, activation of the FceRI signaling system is triggered, leading to the release of granular contents (degranulation) and de novo synthesis and secretion of lipid mediators, cytokines, and chemokines. Activation of MCs entails immediate hypersensitivity and late-phase allergic inflammation. With regard to the IgE-mediated MC activation, recent years have seen a deeper understanding of $\mathrm{IgE}$ synthesis, structural features of allergens, FceRI signaling mechanisms, and counter-mechanisms. Non-IgE-dependent MC activation mechanisms have been studied at a slow pace for many years. However, we have witnessed significant progress in this area more recently.

Murine MCs are classified as connective tissue MCs (CTMCs) and mucosal MCs (MMCs) on the basis of their tissue distribution. CTMCs and MMCs are also characterized by the heparin content of their granules: CTMCs contain a large amount of heparin in their granules, whereas MMCs have very little or no heparin. Human MC proteases include tryptases (mMCP-6 and -7 in mouse), chymases (mMCP-1, -2 , and -4 ), an elastase (mMCP-5), and a carboxypeptidase-A3 (CPA3). Human MCs are categorized by expression of $\mathrm{MC}$ tryptase $\left(\mathrm{MC}_{\mathrm{T}}\right)$ or $\mathrm{MC}$ chymase $\left(\mathrm{MC}_{\mathrm{C}}\right)$ or both $\left(\mathrm{MC}_{\mathrm{TC}}\right)^{1}$. A recent transcriptional analysis demonstrated that the $\mathrm{MC}$ is one of the most transcriptionally variable cell types of the immune system ${ }^{2}$. Murine MCs that were purified from different tissues shared an "MC-specific" transcriptional signature of at least 100 genes. Also, these MCs showed a tissue-specific regulation of their transcriptomes.

Substantial progress has recently been made in several areas of MC research, such as degranulation machinery, cancer, microbiota, and food allergy. Readers interested in these topics are referred to recent review articles ${ }^{3-8}$.

\section{Allergen, immunoglobulin E, and FceRI}

A comprehensive understanding of the IgE-mediated MC activation requires a better knowledge of allergens, IgE synthesis and structure, and FceRI structure and signaling pathways. Here, we highlight recent advances in this area, particularly allergens and IgE synthesis. We certainly know three-dimensional structures of many parts of $\operatorname{IgE}$ and FceRI (composed of an IgE-binding $\alpha$ and receptor-stabilizing and signal-amplifying $\beta$ and activation signal-triggering $\gamma$ subunits $)^{9,10}$ and important principles in signaling, such as tyrosine phosphorylation of $\beta$ and $\gamma$ subunits at the immunoreceptor tyrosine-based activation motif (ITAM) by Src family kinases, the essential functions of Syk, $\mathrm{Ca}^{2+}$ flux, several adaptor molecules, mitogenactivated protein kinases (MAPKs), and several transcription factors $^{11,12}$.
However, we feel obliged to note that our understanding of FceRI signaling pathways is still in the early stages in light of an incomplete understanding of degranulation processes and a large number of genes regulated by MC activation.

One of the most important hypotheses on structural features of allergens stemmed from the requirement of cross-linking of cell surface $\mathrm{IgE}$ molecules by various allergens for MC activation and IgE synthesis. This line of thinking led Jensen-Jarolim et al. to recognize that allergens display repetitive motifs, which they designate allergen-associated molecular patterns ${ }^{13,14}$. Indeed, many allergenic molecules occur as dimers or multimers. Some allergens-small proteins, in particular-have just a single immunodominant B-cell epitope and thus do not fulfill the requirement for cross-linking as a single molecular unit. Oligomerization provides the necessary means for efficient $\operatorname{IgE}$ cross-linking. Examples where only single dominant epitopes have been found are the allergens Der $\mathrm{p} 1$ from house dust mite (HDM) and Bet v 1 from birch. Also, the occurrence of repetitive epitopes on single native allergen molecules has been shown on high-molecular-weight proteins of wheat and for HDMs and insects, cockroach Bla g 1, latex Hev b 5, and tropomyosin from shrimp.

IgE concentrations in serum are kept to the lowest level among immunoglobulin subtypes by several layers of regulation: in addition to the high rate of turnover, low efficiency of classswitch recombination to $\mathrm{IgE}$, and lower surface expression of membrane $\operatorname{IgE}$ than that of $\operatorname{IgG} 1$ on germinal center (GC) $\mathrm{B}$ cells, $\mathrm{IgE}^{+} \mathrm{B}$ cells are predisposed to swiftly exit GCs and differentiate into plasma cells (PCs) and IgE-producing GC $\mathrm{B}$ cells die by apoptosis ${ }^{15-17}$. Therefore, $\operatorname{IgE}^{+}$memory $\mathrm{B}$ cells are scarce $^{18}$. Class switching of antigen-specific $\operatorname{IgG1}^{+}$cells to become $\mathrm{IgE}^{+}$cells, via the so-called sequential switching, was proposed as the mechanism involved in the production of affinity-matured $\operatorname{IgE}$ antibodies in memory responses ${ }^{19}$. Using a culture system of induced GC B cells, Haniuda et al. showed that the CD19-phosphatidylinositol 3-kinase (PI3K)-Akt-IRF4 axis is the essential pathway for PC differentiation and the BLNK-JNK-p38 axis serves an enhancing role in PC differentiation ${ }^{20}$. They also showed that BLNK is essential for B-cell apoptosis and that CD19 is rather anti-apoptotic.

Recent studies have shown that $\mathrm{T}$ follicular helper (Tfh) cells are the primary $\mathrm{T}$-cell subset responsible for $\mathrm{IgE}$ responses. Interleukin-4 (IL-4) is required to generate and sustain $\mathrm{IgE}$ production in mice $^{21}$. In response to allergens, $\mathrm{T}$ helper type 2 (Th2) and Tfh cells show unique cytokine responses, tissue localization, and phenotypes. In vivo, Tfh cells assist the sustained production of IgE antibody. But conditional deficiency of $\mathrm{Bcl6}$, the master regulator of $\mathrm{Tfh}$, in $\mathrm{CD}^{+} \mathrm{T}$ cells ${ }^{22}$ results in a significant decrease in $\mathrm{IgE}$ antibody levels and $\mathrm{Tfh}$ cell numbers. However, eosinophilic inflammation and type 2 cytokine responses in the airways are not affected. Thus, Tfh-derived IL-4, but not Th2-derived IL-4, is necessary for IgE production $^{23}$. Gowthaman et al. recently discovered a new Tfh subset in mice with $\mathrm{T}$ cell-specific Dock8 deficiency ${ }^{24}$. These mice made allergen-specific anaphylactic IgE with the help 
of an IL-4- and IL-13-producing Tfh cell population called Tfh13 cells. Tfh13 cells have an unusual cytokine profile (IL-13 ${ }^{\text {hi }} I L-4^{\text {hi }} I L-5^{\text {hi }} I L-21^{\text {lo }}$ ) and co-express the transcription factors Bcl6 and GATA3. These cells are required for production of high- but not low-affinity $\operatorname{IgE}$ and subsequent allergen-induced anaphylaxis. Single-cell RNA sequencing analysis confirmed that Tfh13 cells are distinct from related Th2 or IL-4-expressing Tfh2 cells. Conditional ablation of Tfh13 cells or isolated loss of IL-13 in Tfh cells resulted in impaired anaphylactic IgE responses to allergens. Thus, blocking Tfh cells might represent a therapeutic means to ameliorate anaphylaxis.

We have known effects of monomeric IgE on FceRI surface levels ${ }^{25,26}$ and on survival of $\mathrm{MCs}^{27,28}$ in the absence of allergen for a long time. A recent study showed that IL-3 but not monomeric IgE regulates FceRI expression and cell survival in primary human basophils, in contrast to human and murine $\mathrm{MCs}^{29}$.

\section{Mast cell activation by interleukin-33}

IL-33 belongs to the IL-1 family and is expressed by several cell types, including epithelial cells ${ }^{30-33}$. IL-33 binds to a specific receptor called T1/ST2 (ST2) that belongs to the Toll-like receptor/IL1R family. ST2 forms heterodimers with the IL-1 receptor accessory protein (IL-1RAcP), namely a transmembrane form (ST2 or ST2L) and a soluble form (sST2). ST2L isoform is expressed on MCs, basophils, Th2 cells, and natural killer cells and coordinates spatially and temporally with IL-33 signaling, which might trigger a key regulatory amplification loop involved in immune homeostasis. IL-33 is considered an alarmin as it is released after necrosis or tissue damage. However, apoptosis leads to the inactivation of IL-33 by cleavage of IL-33 by caspases. In contrast, MC serine proteases cleave the full-length IL-33 (IL-33 ${ }_{1-270}$ ) and liberate active forms: IL-33 ${ }_{95-270}$, IL-33 $3_{99-270}$, and IL-33 ${ }_{109-270}$. These cleaved forms have 10 times greater potency than the full-length protein $^{34}$. MC chymase also degrades IL-33 that leads to higher bioactivity ${ }^{35}$. Downstream of ST2, the IL-33-mediated (B)ignaling pathway involves MyD88, IRAK1, IRAK4, and TRAF6 as well as activation of MAPKs (ERK1/2, p38, and $\mathrm{JNK} 1 / 2)$ and nuclear factor-kappa B (NF- $\mathrm{KB})^{36,37}$.

IL-33 can induce full activation of MCs, including degranulation $^{38}$ and production of several cytokines and chemokines $^{39}$, and elicits systemic MC-dependent anaphylaxis ${ }^{38}$. Several studies have shown that IL-33 plays a significant role in severe asthma ${ }^{40}$ and refractory nasal polyposis ${ }^{41}$. Earlier studies have been summarized in excellent reviews ${ }^{42-44}$. Here, we touch on newer reports that showed a possible role of IL-33 in various allergic conditions: IL-33-mediated airway constriction was exacerbated through increased secretion of serotonin from $\mathrm{MCs}^{45}$. Staphylococcus aureus-derived serine protease-like protein (Spl) D is a potent allergen and induces a Th2-biased inflammatory response in the airways in an IL-33-dependent manner ${ }^{46}$. Aspirin-exacerbated respiratory disease (AERD) is a severe eosinophilic disorder of the airways and is characterized by overproduction of cysteinyl leukotrienes, activation of airway
MCs, and bronchoconstriction in response to non-selective cyclooxygenase inhibitors that deplete prostaglandin $\mathrm{E}_{2}\left(\mathrm{PGE}_{2}\right)$ (Figure 1). A study using clinical samples and mice deficient in $\mathrm{PGE}_{2}$ synthase (a model of AERD) found up-regulation of IL-33 in airway epithelium ${ }^{47}$. Deletion of leukotriene C4 synthase in the AERD model mice eliminates the increased IL-33, lung eosinophilia, and aspirin-induced MC activation and bronchoconstriction. MCs have been shown to play a crucial role in a model of skin inflammation by IL-33-mediated recruitment of leukocytes and resulting inflammation in an MK2/3 (MAPK-activated protein kinases 2 and 3)-dependent manner ${ }^{48}$. In a murine model of food allergy, IL-33 and MCs promote inflammation in the gastrointestinal tract through IL-4 production by IL-33-stimulated ILC2s, as IL-4 blocks the generation of allergen-specific regulatory $\mathrm{T}$ (Treg) cells ${ }^{49-51}$. However, on the positive side, IL-33 and MCs play a protective role in intestinal helminth infections by activating ILC2, leading to helminth expulsion ${ }^{52}$. MCs can ameliorate IL-33-mediated inflammatory effects under certain circumstances. Stimulation of MCs with IL-33 in the absence of IgE cross-linking can induce Treg cell expansion by producing IL-2 and reduce the inflammation in a papain-induced innate-type airway inflammation model ${ }^{53}$.

\section{Mast cell activation via Mrgprb2/MRGPRX2}

Mas-related G protein-coupled receptor-X2 (MRGPRX2) has been the hottest receptor in MC research over the last few years ${ }^{54}$. Mrgprb2 is the murine ortholog of MRGPRX2. Under homeostatic conditions, CTMCs in the skin and peritoneum of mice express Mrgprb2, whereas MMCs do not express Mrgprb25. Mrgprb2/MRGPRX2 recognizes a wide range of cationic molecules, including substance P (SP), basic secretagogues (for example, compound 48/80), numerous US Food and Drug Administration-approved drugs, and endogenous protein fragments ${ }^{55-57}$. Mrgprb2/MRGPRX2-mediated activation of MCs by these ligands results in their rapid degranulation of individual granules and MC-dependent local inflammation, whereas FceRI-elicited secretion is delayed but progressive and is characterized by granule-to-granule fusions ${ }^{58}$.

MRGPRX2 has been implicated in allergic and chronic inflammatory diseases. LL-37, the catheliciden peptide and MRGPRX2 agonist $^{59,60}$, is up-regulated in rosacea ${ }^{61}$, and MCs play a key role as the primary source of LL-37 in a murine model of rosacea ${ }^{62}$. The pathology in asthma ${ }^{63}$ and urticaria $^{64}$ correlates with MC-specific expression of MRGPRX2. Mrgprb2 inactive mutant Mrgprb2 ${ }^{\text {mut/mut }}$ mice $^{55}$ show reduced itch in multiple models of allergic contact dermatitis (ACD), a pruritic inflammatory skin disorder. MC numbers and PAMP1-20 (MRGPRX2 agonist) concentrations are increased in human ACD skin ${ }^{65}$, which is associated with pathogenic CD8 T-cell responses ${ }^{66}$. MCs are found in close proximity to peripheral nerve endings ${ }^{67-69}$. Atopic dermatitis, another pruritic skin disease, has been studied by using a mouse model sensitized and challenged with HDMs in the presence of staphylococcal enterotoxin $\mathrm{B}^{70}$. Using this model, a recent study shows that HDMs with cysteine protease activity directly activate peptidergic nociceptors on sensory neurons expressing the ion channel TRPV1 and 


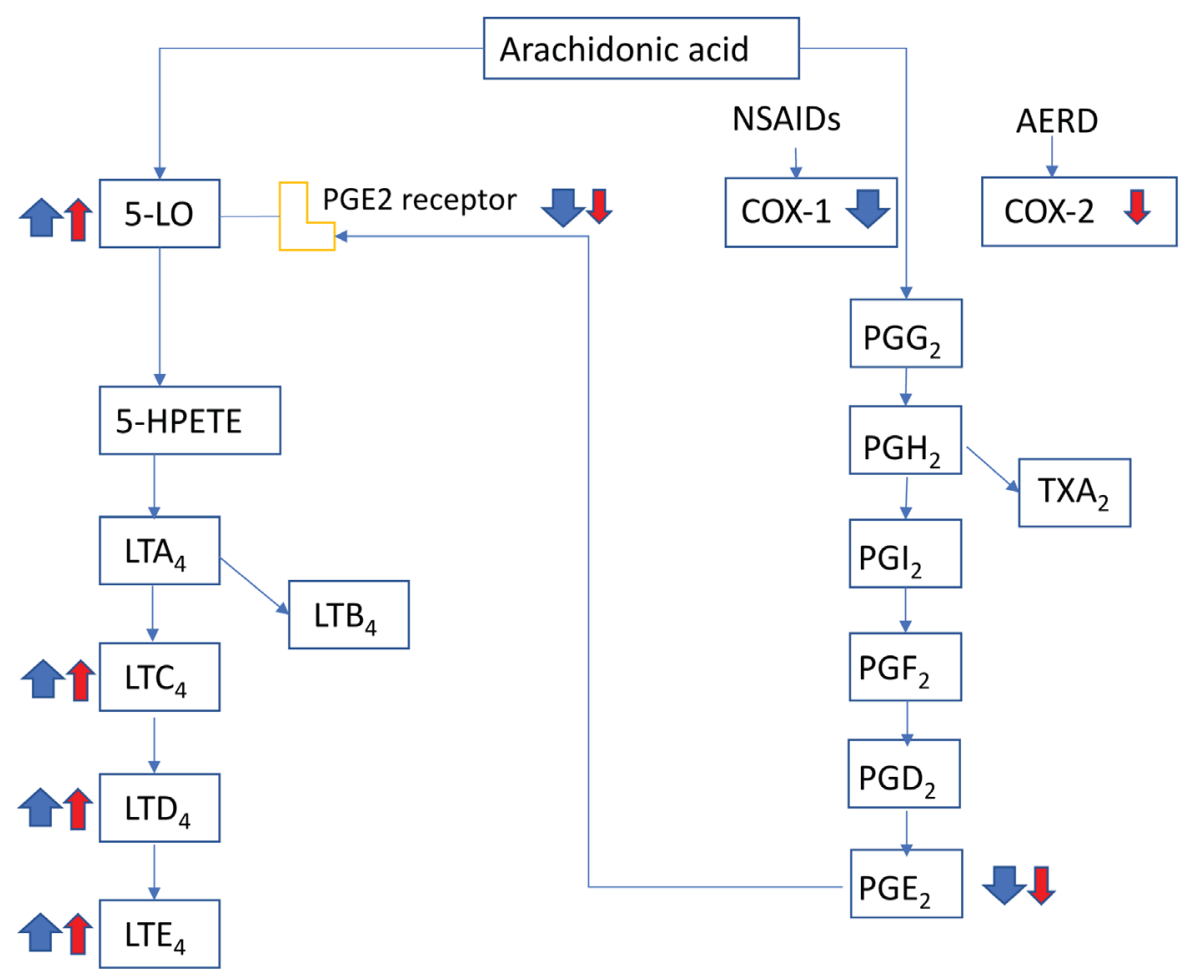

Figure 1. Mechanisms underlying response to cyclooxygenase 1 (COX-1) inhibitors in patients with aspirin-exacerbated respiratory disease (AERD). Patients with AERD show lower levels of COX-2 compared with the healthy population. Non-steroidal anti-inflammatory drugs (NSAIDs) inhibit COX-1 and lower the level of prostaglandin $E_{2}\left(P_{G} E_{2}\right)$. The loss of PGE inhibitory control leads to massive release of histamine and generation of cysteinyl leukotrienes by mast cells, an event that is unique to AERD. Red arrows represent abnormal baseline conditions in patients with AERD, and blue arrows indicate changes after COX-1 inhibition. The size of the arrows indicates the magnitude of change. 5-HPETE, 5-hydroperoxyeicosatetraenoic acid; 5-LO, 5-lipoxygenase; LT, leukotriene (A4, C4, D4, and E4); PG, prostaglandin (G2, $\mathrm{H} 2$, I2, and F2); TXA2, thromboxane A2.

Tacl (gene encoding the precursor for SP) ${ }^{71}$. HDM-activated nociceptors drive the development of allergic skin inflammation by SP/Mrgprb2-mediated activation of $\mathrm{MCs}^{71}$. Another study indicates that activation of the natriuretic polypeptide b (Nppb)-expressing class of sensory neurons elicits scratching responses in mice ${ }^{72}$. Interestingly, however, $\mathrm{Nppb}^{+}$neurons express receptors for leukotrienes, serotonin and sphingosine-1phosphate, and these receptors induce itch by the direct activation of $\mathrm{Nppb}^{+}$neurons and neurotransmission through the canonical gastrin-releasing peptide-dependent spinal cord itch pathway $^{72}$. Mrgprb2/MRGPRX2 is also involved in inflammatory mechanical and thermal hyperalgesia ${ }^{73}$. In this case, SP activates MCs via Mrgprb2/MRGPRX2 to release multiple pro-inflammatory cytokines and chemokines, which facilitate the migration of immune cells. It is noteworthy that SP-mediated activation of MCs does not involve its canonical receptor, neurokinin 1 receptor (NK-1R). However, activation of NK-1R by hemokinin-1 likely contributes to allergic airway inflammation in mice, whereas activation of the human MC line LAD-2 by hemokinin-1 requires MRGPRX2. MRGPRX2 expression is upregulated in lung MCs from patients with lethal asthma ${ }^{63}$.

Studies of Mrgprb2/MRGPRX2-mediated MC activation have been extended to their new ligands, signal transduction, effects of other MC modulators, and so on. For example, compound 48/80, AG-30/5C (angiogenic defense peptide), and icatibant (bradykinin $\mathrm{B} 2$ receptor antagonist) all activate pertussis toxin-sensitive G proteins, but only compound 48/80 activates $\beta$-arrestin ${ }^{74}$. The same study also found resveratrol (polyphenolic compound in peanuts, grapes, red wine, and some berries) as an inhibitor of MRGPRX2. As the FceRI signaling is initiated by tyrosine phosphorylation with Src, Syk, and Tec family kinases while Mrgprb2 and MRGPRX2 are G protein-coupled receptors, FceRI- and MRGPRX2-stimulated pathways are completely independent of each other ${ }^{75}$. Stem cell factor (SCF) and IL-4, which are the two main MC differentiation and growth factors, negatively regulate MRGPRX2 expression in human skin MCs, whereas SCF promotes allergic stimulation via FceRI ${ }^{76}$. In contrast, pre-incubation (20 minutes) of human MCs with IL-33 or IL-6 or both does not affect their activation with SP, whereas such priming, particularly that with both IL-33 and IL-6, enhances IgE/allergen-mediated MC activation ${ }^{77}$. Another study shows that chronic exposure (5 weeks) of human MCs to IL-33 reduces FceRI expression and responsiveness to its aggregation ${ }^{78}$. Short-term (30 minutes) pre-incubation with IL-33 enhances MRGPRX2-mediated degranulation by SP or compound 48/80 without changing MRGPRX2 expression, whereas chronic (5 weeks) pre-treatment with IL-33 reduces 
mRNA and protein expression of MRGPRX2 and its function ${ }^{79}$. MCs are also required for cardiac fibrosis in multiple animal models. Interestingly, NK-1R expression in MCs is not required in cardiac fibrosis ${ }^{80}$. It should be tested whether Mrgprb2 is involved in this process.

\section{MicroRNA and mast cell biology}

MicroRNA (miRNA), a small non-coding RNA molecule that is 19 to 25 nucleotides in length, functions in post-transcriptional regulation and RNA silencing of gene expression. miRNAs work by base pairing with complementary sequences inside of mRNA molecules. Because of the broad regulatory mechanisms, miRNAs regulate differentiation, proliferation, survival, apoptosis, stress response, and the effector function as well as the resolution of an immune response ${ }^{81,82}$.

Numerous studies have examined the role of miRNAs in MC biology (Table 1$)^{83}$. Silencing of Dicer, a key enzyme of miRNA biogenesis, attenuates degranulation, indicating that miRNAs are involved in MC activation. Overexpression of miR-142$3 p$, which rescues Dicer expression, enhances FceRI-mediated degranulation in $\mathrm{MCs}^{84}$. IgE/antigen stimulation of bone marrow-derived MCs induces up- or down-regulation of several miRNAs, which affects mRNA expression of some key signaling molecules, including Lyn, Vav3, and Csf $2^{85,86}$. miR-155 plays a critical role in FceRI-mediated MC responses by modulating components of the $\mathrm{PI} 3 \mathrm{~K} \gamma$ pathway, and miR-155-deficient mice show enhanced anaphylaxis ${ }^{87}$. Downregulation of miR-155 in MCs is also involved in suppression of IL-33-induced inflammation by lactic acid ${ }^{88}$ or of IL-33-induced IL-6 production in $\mathrm{MCs}^{89}$. As a basis of IL-10-mediated MC regulation, IL-10-induced miR-155 expression enhances protease and cytokine production in MCs by suppressing SOCS1, a suppressor of cytokine signaling ${ }^{90}$. A novel miRNA let7i inhibits MC degranulation by suppressing expression of Exoc8, which is an exocytosis-related gene $^{91}$. MiR-126 accelerates IgE-mediated MC degranulation, which is associated with PI3K/Akt activation and increased $\mathrm{Ca}^{2+}$ influx ${ }^{92}$. MiR-223 reduces IL-6 secretion in MCs by inhibiting the IGF1R/PI3K signaling pathway ${ }^{93}$. Expression of miR-210 and miRNA-132/212 cluster is increased by IgE-mediated MC activation $^{94}$. MiR-21 inhibits MC degranulation by inhibiting the p38 pathway in a murine model of $\mathrm{ACD}^{95}$. MiR-221-222 is up-regulated in $\mathrm{MC}$ stimulation and regulates the cell cycle by

Table 1. MicroRNA (miRNA) functions in mast cell activation and proliferation.

\begin{tabular}{|c|c|c|c|c|}
\hline miRNA & Trigger & miRNA effect on mast cells & $\begin{array}{l}\text { Target } \\
\text { mRNA }\end{array}$ & References \\
\hline miR-142 & FceRl & Increase degranulation & & 81 \\
\hline miR-155 & $\begin{array}{l}\text { FceRI } \\
\text { IL-33 } \\
\text { IL-10 }\end{array}$ & $\begin{array}{l}\mathrm{Ca}^{2+} \text { influx with degranulation } \\
\text { Increase cytokine production } \\
\text { Increase cytokine production }\end{array}$ & $\begin{array}{l}\text { PI3K } \\
\text { SOCS1 }\end{array}$ & $84-87$ \\
\hline Let-7i & & Decrease degranulation & Exoc8 & 88 \\
\hline miR-126 & FceRl & Increases degranulation & & 89 \\
\hline miR-223 & FceRl & $\begin{array}{l}\text { Decrease granulation and interluekin-6 (IL-6) } \\
\text { release }\end{array}$ & IGF1R & 90 \\
\hline miR-210 & FceRl & & & 91 \\
\hline miR-132/212 & FceRl & & HB-EGF & 91 \\
\hline miR-21 & Allergic inflammation & Decrease degranulation and IL-12 production & $\begin{array}{l}\text { IL-12p35 } \\
\text { P38 }\end{array}$ & 92 \\
\hline miR-221/222 & FceRl & $\begin{array}{l}\text { Regulate proliferation and cell cycle } \\
\text { Increases degranulation and cytokine } \\
\text { production; reduces migration }\end{array}$ & p27 $7^{\mathrm{Kip} 1}$, PTEN & 93-95 \\
\hline miR-302e & $\begin{array}{l}\text { FcERI } \\
\text { PMA/IONO }\end{array}$ & Decrease cytokine secretion & RelA & 96 \\
\hline miR-146 & FceRl & Reduces activation & $\begin{array}{l}\text { TRAF6, } \\
\text { IRAK1 }\end{array}$ & 97-99 \\
\hline miR-143 & Allergic inflammation & Down-regulate allergic response & IL-13R $\alpha 1$ & 100 \\
\hline miR-20a & PMA/IONO & $\begin{array}{l}\text { Activate mast cells (MCs) } \\
\text { Inhibit production of pro-inflammatory cytokines }\end{array}$ & HDAC4 & 101 \\
\hline miR-4443 & $\begin{array}{l}\text { T cell-derived } \\
\text { microvesicle }\end{array}$ & Increase ERK phosphorylation and IL-8 release & PTPRJ & $102-108$ \\
\hline miR-490 & HCV-E2 & Inhibits tumor metastasis & & 109 \\
\hline miR-9 & & Increase invasion of neoplastic MCs & & 110 \\
\hline miR-122 & Tumor response & Decrease activation & SOCS1 & 111 \\
\hline
\end{tabular}


inhibiting p27 ${ }^{\mathrm{Kip} 1}$ expression ${ }^{96,97}$. MiR-221-3p, which is markedly increased in asthmatics, up-regulates IL-4 secretion from MCs by targeting phosphatase and tensin homolog (PTEN) as well as activation of $\mathrm{p} 38$ and $\mathrm{NF}-\mathrm{\kappa B}^{98}$. MiR-302e negatively regulates $\mathrm{RelA} / \mathrm{p} 65$ expression in $\mathrm{MCs}$ and ameliorates allergic inflammation through inhibition of the NF- $\mathrm{KB}$ signaling pathway ${ }^{99}$. MiR-143 and miR-146 reduce MC activation by targeting IL-13R $\alpha 1$ and TRAF/IRAK, respectively, leading to a reduced allergic response ${ }^{100-103}$. miR-20a inhibits expression of tumor necrosis factor (TNF), IL-1 $\beta$, and interferon gamma (IFN- $\gamma$ ) while promoting IL-10 in HMC-1 human MCs. miR-20a also targets histone deacetylase 4 (HDAC4), which contributes to the epigenetic regulation of IL-10 expression ${ }^{104}$.

Shefler et al. showed that MCs are activated by interaction with activated $\mathrm{T}$ cells or their microvesicles $\left(\mathrm{mvT}^{*} \mathrm{~s}\right)^{105,106}$. The physical contact of MCs with activated $\mathrm{T}$ cells or with mvT*s induces Ras activation and ERK phosphorylation, leading to degranulation and release of several cytokines in MCs ${ }^{106-110}$. The same group later found that miR-4443 in $\mathrm{mvT}^{*} \mathrm{~s}$ targets the expression of protein tyrosine phosphatase receptor type $\mathrm{J}$ (PTPRJ), a known ERK inhibitor ${ }^{111}$. Several miRNAs that play a role in cancer have recently been discovered: miR-9 increases the invasion of neoplastic $\mathrm{MCs}^{112}$. miR-122 targets SOCS1 mRNA and regulates cellular interactions involving cancer cells, MCs, and macrophages during allergic inflammation ${ }^{113}$. Exosomal miRNAs have emerged as mediators of the interaction between MCs and tumor cells. MCs can inhibit hepatocellular carcinoma cell metastasis by inhibiting the ERK1/2 pathway by transferring the exosomal shuttle microRNAs, including miR-490, into hepatocellular carcinoma cells ${ }^{114}$.

\section{Perspectives on mast cells in diseases}

Traditionally, MCs have been implicated in allergic diseases. Efficacy of omalizumab-humanized anti-IgE monoclonal antibody (mAb) - and mAbs targeting Th2 cytokines or Th2 cytokine receptors for the treatment of asthma and other allergic diseases supports crucial pathogenic roles for MCs in these diseases $^{115-117}$. Among the mAbs targeting cytokine/receptors, the most illustrative example is dupilumab (mAb for IL4R $\alpha$, the subunit shared by IL-4 and IL-13 receptors). This mAb blocks the functions of both IL-4 and IL-13 and is highly efficacious for the treatment of atopic dermatitis ${ }^{118}$ and asthma ${ }^{119,120}$. However, effects of dupilumab likely reflect pleiotropic functions of IL-4 and IL-13 in immune and non-immune cells.

MCs are considered an important player in inflammation-associated diseases in general, as recent studies have extended their potential role in other diseases. For example, MCs seem to be involved in gastrointestinal diseases such as inflammatory bowel disease, celiac disease, and irritable bowel syndrome ${ }^{121}$. The phenotype and the activation status of MCs rather than the absolute numbers in the intestinal mucosa are important for the development and progression of the diseases ${ }^{122}$. MCs might also play a role in atherosclerosis. Immunohistochemical studies in autopsied human subjects and studies in murine atherosclerotic models have collectively provided evidence that the compounds released by activated MCs might promote atherogenesis at various stages during the development of atherosclerotic lesions ${ }^{123}$. MCs can be pro-tumorigenic and anti-tumorigenic ${ }^{4,124}$. A recent study found that immune cells such as MCs, tumor-associated neutrophils, tumor-infiltrating macrophages, and myeloid-derived suppressor cells promote prostate cancer via various types of intercellular signaling ${ }^{125}$. With regard to neural diseases, MCs might contribute to modulate the intensity of the associated depressive and anxiogenic component on the neuronal and microglial biological front ${ }^{126}$. Preclinical evidence suggests that the intestinal microbiota contributes significantly to behavioral and mood disorders. Microbiotic conditions have been linked to pain, anxiety, stress, and depression in humans ${ }^{126}$. Far from being substantiated by other studies, symptoms of autism spectrum disorder might also be caused by the mediators derived from MCs which could activate microglia, causing localized inflammation ${ }^{127}$. MCs might play a significant role as a neuroimmune connection between these components. The next decade might see unexpected developments in MC research and their clinical translations.
1. Pejler G, Abrink M, Ringvall M, et al.: Mast cell proteases. Adv Immunol. 2007; 95 167-255.

PubMed Abstract | Publisher Full Text

2. F Dwyer DF, Barrett NA, Austen KF: Expression profiling of constitutive mast cells reveals a unique identity within the immune system. Nat Immunol. 2016; 17(7): 878-87.

PubMed Abstract | Publisher Full Text | Free Full Text | F1000 Recommendation

3. F Klein O, Sagi-Eisenberg R: Anaphylactic Degranulation of Mast Cells: Focus on Compound Exocytosis. J Immunol Res. 2019; 2019: 9542656.

PubMed Abstract | Publisher Full Text | Free Full Text | F1000 Recommendation

4. Varricchi G, Galdiero MR, Loffredo S, et al.: Are Mast Cells MASTers in Cancer? Front Immunol. 2017; 8: 424.

PubMed Abstract | Publisher Full Text | Free Full Text

5. Igawa S, Di Nardo A: Skin microbiome and mast cells. Transl Res. 2017; 184: 68-76.

PubMed Abstract | Publisher Full Text | Free Full Text
6. Zuani M, Secco C, Frossi B: Mast cells at the crossroads of microbiota and IBD. Eur J Immunol. 2018; 48(12): 1929-37.

PubMed Abstract | Publisher Full Text

7. Yu W, Freeland DMH, Nadeau KC: Food allergy: immune mechanisms, diagnosis and immunotherapy. Nat Rev Immunol. 2016; 16(12): 751-65. PubMed Abstract | Publisher Full Text | Free Full Text

8. Tordesillas L, Berin MC, Sampson HA: Immunology of Food Allergy. Immunity. 2017; 47(1): 32-50.

PubMed Abstract | Publisher Full Text

9. Kinet JP: The high-affinity IgE receptor (Fc epsilon RI): from physiology to pathology. Annu Rev Immunol. 1999; 17: 931-72. PubMed Abstract | Publisher Full Text

10. Gould HJ, Sutton BJ, Beavil AJ, et al:: The biology of IGE and the basis of allergic disease. Annu Rev Immunol. 2003; 21: 579-628. PubMed Abstract | Publisher Full Text

11. Gilfillan AM, Tkaczyk C: Integrated signalling pathways for mast-cell activation. 
Nat Rev Immunol. 2006; 6(3): 218-30.

PubMed Abstract | Publisher Full Text

12. Gilfillan AM, Rivera J: The tyrosine kinase network regulating mast cell activation. Immunol Rev. 2009; 228(1): 149-69.

PubMed Abstract | Publisher Full Text | Free Full Text

13. Jensen-Jarolim E, Mechtcheriakova D, Pali-Scholl I: Cancer and IgE. Introducing the Concept of AllergoOncology. (eds E. Jensen-Jarolim \& Penichet M.L.) Springer, 2010; 231-254.

Publisher Full Text

14. Pali-Schöll I, Jensen-Jarolim E: The concept of allergen-associated molecular patterns (AAMP). Curr Opin Immunol. 2016; 42: 113-8. PubMed Abstract | Publisher Full Text

15. F Yang Z, Sullivan BM, Allen CD: Fluorescent in vivo detection reveals that $\lg \mathrm{E}(+) \mathrm{B}$ cells are restrained by an intrinsic cell fate predisposition. Immunity. 2012; 36(5) 857-72.

PubMed Abstract | Publisher Full Text | F1000 Recommendation

16. $\quad \mathrm{F}_{\mathrm{He}} \mathrm{JS}$, Meyer-Hermann M, Xiangying D, et al.: The distinctive germinal center phase of IgE+ B lymphocytes limits their contribution to the classical memory response. $J$ Exp Med. 2013; 210(12): 2755-71.

PubMed Abstract | Publisher Full Text | Free Full Text | F1000 Recommendation

17. Laffleur B, Duchez S, Tarte K, et al.: Self-Restrained B Cells Arise following Membrane IgE Expression. Cell Rep. 2015; 10(6): 900-9. PubMed Abstract | Publisher Full Text

18. He JS, Narayanan S, Subramaniam S, et al.: Biology of IgE production: IgE cell differentiation and the memory of IgE responses. Curr Top Microbiol Immunol. 2015; 388: $1-19$ PubMed Abstract | Publisher Full Tex

19. $\mathrm{F}$ Xiong $\mathrm{H}$, Dolpady $\mathrm{J}$, Wabl $\mathrm{M}$, et al.: Sequential class switching is required for the generation of high affinity IgE antibodies. J Exp Med. 2012; 209(2) 353-64

PubMed Abstract | Publisher Full Text | Free Full Text | F1000 Recommendation

20. $\mathrm{F}$ Haniuda $\mathrm{K}$, Fukao S, Kodama $\mathrm{T}$, et al:: Autonomous membrane IgE signaling prevents IgE-memory formation. Nat Immunol. 2016; 17(9): 1109-17. PubMed Abstract | Publisher Full Text | F1000 Recommendation

21. Finkelman FD, Katona IM, Urban JF Jr, et al.: IL-4 is required to generate and sustain in vivo IgE responses. $J$ Immunol. 1988; 141(7): 2335-41. PubMed Abstract

22. Crotty $\mathrm{S}$ : $\mathbf{T}$ follicular helper cell differentiation, function, and roles in disease. Immunity. 2014; 41(4): 529-42.

PubMed Abstract | Publisher Full Text | Free Full Text

23. Kobayashi $\mathrm{T}$, lijima $\mathrm{K}$, Dent $\mathrm{AL}$, et al.: Follicular helper T cells mediate IgE antibody response to airborne allergens. J Allergy Clin Immunol. 2017; 139(1): 300-313.e7.

PubMed Abstract | Publisher Full Text | Free Full Text

24. F Gowthaman U, Chen JS, Zhang B, et al.: Identification of a T follicular helpe cell subset that drives anaphylactic IgE. Science. 2019; 365(6456): pii: eaaw6433.

PubMed Abstract | Publisher Full Text | F1000 Recommendation

25. Hsu C, MacGlashan D Jr: IgE antibody up-regulates high affinity IgE binding on murine bone marrow-derived mast cells. Immunol Lett. 1996; 52(2-3): 129-34. PubMed Abstract | Publisher Full Text

26. Yamaguchi M, Lantz CS, Oettgen HC, et al:: IgE enhances mouse mast cell Fc(epsilon)RI expression in vitro and in vivo: evidence for a novel amplification mechanism in IgE-dependent reactions. J Exp Med. 1997; 185(4): 663-72. PubMed Abstract | Publisher Full Text | Free Full Text

27. Asai K, Kitaura J, Kawakami $\mathrm{Y}$, et al:: Regulation of mast cell survival by IgE. Immunity. 2001; 14(6): 791-800. PubMed Abstract | Publisher Full Text

28. F Kalesnikoff J, Huber M, Lam V, et al:: Monomeric IgE stimulates signaling pathways in mast cells that lead to cytokine production and cell survival. Immunity. 2001; 14(6): 801-11.

PubMed Abstract | Publisher Full Text | F1000 Recommendation

29. F Zellweger F, Buschor P, Hobi G, et al.: IL-3 but not monomeric IgE regulates FceRI levels and cell survival in primary human basophils. Cell Death Dis. 2018; 9(5): 510 .

PubMed Abstract | Publisher Full Text | Free Full Text | F1000 Recommendation

30. F Schmitz J, Owyang A, Oldham E, et al:: IL-33, an interleukin-1-like cytokine that signals via the IL-1 receptor-related protein ST2 and induces T helper type 2-associated cytokines. Immunity. 2005; 23(5): 479-90.

PubMed Abstract | Publisher Full Text | F1000 Recommendation

31. F Hammad H, Chieppa M, Perros F, et al.: House dust mite allergen induces asthma via Toll-like receptor 4 triggering of airway structural cells. Nat Med. 2009: 15(4): 410-6.

PubMed Abstract | Publisher Full Text | Free Full Text | F1000 Recommendation

32. F Moussion C, Ortega N, Girard JP: The IL-1-like cytokine IL-33 is constitutively expressed in the nucleus of endothelial cells and epithelial cells in vivo: a novel 'alarmin'? PLoS One. 2008; 3(10): e3331.

PubMed Abstract | Publisher Full Text | Free Full Text | F1000 Recommendation

33. Wood IS, Wang B, Trayhurn P: IL-33, a recently identified interleukin-1 gene family member, is expressed in human adipocytes. Biochem Biophys Res Commun. 2009; 384(1): 105-9.

PubMed Abstract | Publisher Full Tex

34. Lefrançais E, Cayrol C: Mechanisms of IL-33 processing and secretion: differences and similarities between IL-1 family members. Eur Cytokine Netw. 2012; 23(4): 120-7.

PubMed Abstract | Publisher Full Text

35. Roy A, Ganesh G, Sippola H: Mast cell chymase degrades the alarmins heat shock protein 70, biglycan, HMGB1, and interleukin-33 (IL-33) and limits danger-induced inflammation. $J$ Biol Chem. 2014; 289(1): 237-50.

PubMed Abstract | Publisher Full Text | Free Full Text

36. $\quad \mathrm{F}$ Pinto SM, Subbannayya $\mathrm{Y}$, Rex DA, et al:: A network map of IL-33 signaling pathway. J Cell Commun Signal. 2018; 12(3): 615-24.

PubMed Abstract | Publisher Full Text | Free Full Text | F1000 Recommendation

Kakkar R, Lee RT: The IL-33/ST2 pathway: therapeutic target and novel biomarker. Nat Rev Drug Discov. 2008; 7(10): 827-40.

PubMed Abstract | Publisher Full Text | Free Full Text

38. Komai-Koma M, Brombacher F, Pushparaj PN, et al:: Interleukin-33 amplifies IgE synthesis and triggers mast cell degranulation via interleukin- 4 in naïve mice. Allergy. 2012; 67(9): 1118-26.

PubMed Abstract | Publisher Full Text | Free Full Text

39. Allakhverdi Z, Smith DE, Comeau MR, et al:: Cutting edge: The ST2 ligand IL-33 potently activates and drives maturation of human mast cells. $J$ Immunol. 2007; 179(4): 2051-4.

PubMed Abstract | Publisher Full Text

40. Guo Z, Wu J, Zhao J, et al:: IL-33 promotes airway remodeling and is a marker of asthma disease severity. J Asthma. 2014; 51(8): 863-9. PubMed Abstract | Publisher Full Text

41. Reh DD, Wang $\mathrm{Y}$, Ramanathan M Jr, et al.: Treatment-recalcitrant chronic rhinosinusitis with polyps is associated with altered epithelial cell expression of interleukin-33. Am J Rhinol Allergy. 2010; 24(2): 105-9. PubMed Abstract | Publisher Full Text | Free Full Text

42. F Liew FY, Girard JP, Turnquist HR: Interleukin-33 in health and disease. Nat Rev Immunol. 2016: 16(11): 676-89.

PubMed Abstract | Publisher Full Text | F1000 Recommendation

43. Saluja R, Khan M, Church MK, et al.: The role of IL-33 and mast cells in allergy and inflammation. Clin Transl Allergy. 2015; 5: 33.

PubMed Abstract | Publisher Full Text | Free Full Text

44. Makrinioti $\mathrm{H}$, Toussaint M, Jackson DJ, et al:: Role of interleukin $\mathbf{3 3}$ in respiratory allergy and asthma. Lancet Respir Med. 2014; 2(3): 226-37.

PubMed Abstract | Publisher Full Text

45. Sjöberg LC, Gregory JA, Dahlén SE, et al:: Interleukin-33 exacerbates allergic bronchoconstriction in the mice via activation of mast cells. Allergy. 2015; 70(5): 514-21.

PubMed Abstract | Publisher Full Text

46. F Teufelberger AR, Nordengrün M, Braun $\mathrm{H}$, et al:: The IL-33/ST2 axis is crucial in type 2 airway responses induced by Staphylococcus aureus-derived serine protease-like protein D. J Allergy Clin Immunol. 2018; 141(2): 549-559.e7. PubMed Abstract | Publisher Full Text | F1000 Recommendation

47. F Liu T, Kanaoka Y, Barrett NA, et al: Aspirin-Exacerbated Respiratory Disease Involves a Cysteinyl Leukotriene-Driven IL-33-Mediated Mast Cell Activation Pathway. J Immunol. 2015; 195(8): 3537-45.

PubMled Abstract | Publisher Full Text | Free Full Text | F1000 Recommendation

48. Drube S, Kraft F, Dudeck J, et al: MK2/3 Are Pivotal for IL-33-Induced and Mast Cell-Dependent Leukocyte Recruitment and the Resulting Skin Inflammation. $J$ Immunol. 2016; 197(9): 3662-8.

PubMed Abstract | Publisher Full Text

49. Noval Rivas M, Burton OT, Oettgen HC, et al.: IL-4 production by group 2 innate lymphoid cells promotes food allergy by blocking regulatory T-cell function. J Allergy Clin Immunol. 2016; 138(3): 801-811.e9. PubMed Abstract | Publisher Full Text | Free Full Text

50. $\quad F$ Leyva-Castillo JM, Galand C, Kam C, et al:: Mechanical Skin Injury Promotes Food Anaphylaxis by Driving Intestinal Mast Cell Expansion. Immunity. 2019; 50(5): 1262-1275.e4

PubMed Abstract | Publisher Full Text | Free Full Text | F1000 Recommendation

51. Galand C, Leyva-Castillo JM, Yoon J, et al:: IL-33 promotes food anaphylaxis in epicutaneously sensitized mice by targeting mast cells. $J$ Allergy Clin Immunol. 2016; 138(5): 1356-66

PubMed Abstract | Publisher Full Text | Free Full Tex

52. F Shimokawa C, Kanaya T, Hachisuka M, et al:: Mast Cells Are Crucial for Induction of Group 2 Innate Lymphoid Cells and Clearance of Helminth Infections. Immunity. 2017; 46(5): 863-874.e4.

PubMed Abstract | Publisher Full Text | F1000 Recommendation

53. Morita H, Arae K, Unno H, et al:: An Interleukin-33-Mast Cell-Interleukin-2 Axis Suppresses Papain-Induced Allergic Inflammation by Promoting Regulatory T Cell Numbers. Immunity. 2015; 43(1): 175-86.

PubMed Abstract | Publisher Full Text | Free Full Text

54. Kawakami T, Kasakura K: Mast Cell Eavesdropping on Bacterial Communications. Cell Host Microbe. 2019; 26(1): 3-5.

PubMed Abstract | Publisher Full Tex

55. F McNeil BD, Pundir P, Meeker S, et al.: Identification of a mast-cell-specific 
receptor crucial for pseudo-allergic drug reactions. Nature. 2015; 519(7542) 237-41

PubMed Abstract | Publisher Full Text | Free Full Text | F1000 Recommendation

56. $\quad \mathrm{F}$ Tatemoto $\mathrm{K}$, Nozaki $\mathrm{Y}$, Tsuda R, et al.: Endogenous protein and enzyme fragments induce immunoglobulin E-independent activation of mast cells via a G protein-coupled receptor, MRGPRX2. Scand J Immunol. 2018; 87(5): e12655. PubMed Abstract | Publisher Full Text | F1000 Recommendation

57. F Pundir P, Liu R, Vasavda C, et al:: A Connective Tissue Mast-Cell-Specific Receptor Detects Bacterial Quorum-Sensing Molecules and Mediates Antibacterial Immunity. Cell Host Microbe. 2019; 26(1): 114-122.e8. PubMed Abstract | Publisher Full Text | Free Full Text | F1000 Recommendation

58. Gaudenzio N, Sibilano R, Marichal T, et al.: Different activation signals induce distinct mast cell degranulation strategies. J Clin Invest. 2016; 126(10): 3981-98.

PubMed Abstract | Publisher Full Text | Free Full Text

59. Subramanian H, Gupta K, Guo Q, et al:: Mas-related gene X2 (MrgX2) is a novel G protein-coupled receptor for the antimicrobial peptide LL-37 in human mast cells: resistance to receptor phosphorylation, desensitization, and internalization. J Biol Chem. 2011; 286(52): 44739-49. PubMed Abstract | Publisher Full Text | Free Full Text

60. Yu Y, Zhang $Y$, Zhang $Y$, et al.: LL-37-induced human mast cell activation through G protein-coupled receptor MrgX2. Int Immunopharmacol. 2017; 49: $6-12$.

PubMed Abstract | Publisher Full Text

61. Reinholz M, Ruzicka T, Schauber J: Cathelicidin LL-37: an antimicrobial peptide with a role in inflammatory skin disease. Ann Dermatol. 2012; 24(2): 126-35. PubMed Abstract | Publisher Full Text | Free Full Text

62. Muto $\mathrm{Y}$, Wang $\mathrm{Z}$, Vanderberghe $\mathrm{M}$, et al:: Mast cells are key mediators of cathelicidin-initiated skin inflammation in rosacea. J Invest Dermatol. 2014; 134(11): 2728-36.

PubMed Abstract | Publisher Full Text | Free Full Text

63. F Manorak W, Idahosa C, Gupta K, et al:: Upregulation of Mas-related G Protein coupled receptor $\mathrm{X} 2$ in asthmatic lung mast cells and its activation by the novel neuropeptide hemokinin-1. Respir Res. 2018; 19(1): 1. PubMed Abstract | Publisher Full Text | Free Full Text | F1000 Recommendation

64. F Fujisawa D, Kashiwakura J, Kita H, et al:: Expression of Mas-related gene $\mathrm{X} 2$ on mast cells is upregulated in the skin of patients with severe chronic urticaria. J Allergy Clin Immunol. 2014; 134(3): 622-633.e9. PubMed Abstract | Publisher Full Text | F1000 Recommendation

65. F Meixiong J, Anderson M, Limjunyawong N, et al:: Activation of MastCell-Expressed Mas-Related G-Protein-Coupled Receptors Drives Nonhistaminergic Itch. Immunity. 2019; 50(5): 1163-1171.e5. PubMed Abstract | Publisher Full Text | Free Full Text | F1000 Recommendation

66. Vocanson $\mathrm{M}$, Hennino $\mathrm{A}$, Rozières $\mathrm{A}$, et al.: Effector and regulatory mechanisms in allergic contact dermatitis. Allergy. 2009; 64(12): 1699-714.

PubMed Abstract | Publisher Full Text

67. Arizono N, Matsuda S, Hattori T, et al:: Anatomical variation in mast cell nerve associations in the rat small intestine, heart, lung, and skin. Similarities of distances between neural processes and mast cells, eosinophils, or plasma cells in the jejunal lamina propria. Lab Invest. 1990; 62(5): 626-34. PubMed Abstract

68. Bienenstock J, MacQueen G, Sestini $P$, et al.: Mast cell/nerve interactions in vitro and in vivo. Am Rev Respir Dis. 1991; 143(3 Pt 2): S55-8. PubMed Abstract | Publisher Full Text

69. Purcell WM, Atterwill CK: Mast cells in neuroimmune function: neurotoxicological and neuropharmacological perspectives. Neurochem Res. 1995; 20(5): 521-32.

PubMed Abstract | Publisher Full Text

70. Kawakami Y, Yumoto K, Kawakami T: An improved mouse model of atopic dermatitis and suppression of skin lesions by an inhibitor of Tec family kinases. Allergol Int. 2007; 56(4): 403-9.

PubMed Abstract | Publisher Full Text

71. F Serhan N, Basso L, Sibilano R, et al:: House dust mites activate nociceptormast cell clusters to drive type 2 skin inflammation. Nat Immunol. 2019; 20(11): 1435-43.

PubMed Abstract | Publisher Full Text | Free Full Text | F1000 Recommendation

72. F Solinski HJ, Kriegbaum MC, Tseng PY, et al.: Nppb Neurons Are Sensors of Mast Cell-Induced Itch. Cell Rep. 2019; 26(13): 3561-3573.e4.

PubMed Abstract | Publisher Full Text | Free Full Text | F1000 Recommendation

73. F Green DP, Limjunyawong N, Gour N, et al:: A Mast-Cell-Specific Receptor Mediates Neurogenic Inflammation and Pain. Neuron. 2019; 101(13): 412-420.e3. PubMed Abstract | Publisher Full Text | Free Full Text | F1000 Recommendation

74. F Roy S, Ganguly A, Haque M, et al:: Angiogenic Host Defense Peptide AG$30 / 5 \mathrm{C}$ and Bradykinin $\mathrm{B}_{2}$ Receptor Antagonist Icatibant Are G Protein Biased Agonists for MRGPRX2 in Mast Cells. J Immunol. 2019; 202(4): 1229-38. PubMed Abstract | Publisher Full Text | Free Full Text | F1000 Recommendation

75. Babina M, Guhl S, Artuc M, et al:: Allergic Fc\&RI- and pseudo-allergic MRGPRX2triggered mast cell activation routes are independent and inversely regulated by SCF. Allergy. 2018; 73(1): 256-60.

PubMed Abstract | Publisher Full Text
76. $\mathrm{F}$ Babina $\mathrm{M}$, Wang $\mathrm{Z}$, Artuc M, et al:: MRGPRX2 is negatively targeted by SCF and IL-4 to diminish pseudo-allergic stimulation of skin mast cells in culture. Exp Dermatol. 2018; 27(11): 1298-303.

PubMed Abstract | Publisher Full Text | F1000 Recommendation

77. F Cop N, Ebo DG, Bridts CH, et al.: Influence of IL-6, IL-33, and TNF- $\alpha$ on human mast cell activation: Lessons from single cell analysis by flow cytometry. Cytometry B Clin Cytom. 2018; 94(3): 405-11. PubMed Abstract | Publisher Full Text | F1000 Recommendation

78. F Babina M, Wang Z, Franke K, et al.: Yin-Yang of IL-33 in Human Skin Mast Cells: Reduced Degranulation, but Augmented Histamine Synthesis through p38 Activation. J Invest Dermatol. 2019; 139(7): 1516-1525.e3. PubMed Abstract | Publisher Full Text | F1000 Recommendation

79. F Wang Z, Guhl S, Franke K, et al.: IL-33 and MRGPRX2-Triggered Activation of Human Skin Mast Cells-Elimination of Receptor Expression on Chronic Exposure, but Reinforced Degranulation on Acute Priming. Cells. 2019; 8(4): pii: E341.

PubMed Abstract | Publisher Full Text | Free Full Text | F1000 Recommendation

80. F Widiapradja A, Manteufel EJ, Dehlin HM, et al.: Regulation of Cardiac Mast Cell Maturation and Function by the Neurokinin-1 Receptor in the Fibrotic Heart. Sci Rep. 2019; 9(1): 11004.

PubMed Abstract | Publisher Full Text | Free Full Text | F1000 Recommendation

81. Bartel DP: MicroRNAs: target recognition and regulatory functions. Cell. 2009; 136(2): 215-33

PubMed Abstract | Publisher Full Text | Free Full Text

82. Chiang HR, Schoenfeld LW, Ruby JG, et al:: Mammalian microRNAs: experimental evaluation of novel and previously annotated genes. Genes Dev. 2010; 24(10): 992-1009.

PubMed Abstract | Publisher Full Text | Free Full Text

83. Shefler I, Salamon P, Mekori YA: MicroRNA Involvement in Allergic and NonAllergic Mast Cell Activation. Int J Mol Sci. 2019; 20(9): 2145. PubMed Abstract | Publisher Full Text | Free Full Text

84. Yamada $\mathrm{Y}$, Kosaka K, Miyazawa $\mathrm{T}$, et al:: miR-142-3p enhances FceRI-mediated degranulation in mast cells. Biochem Biophys Res Commun. 2014; 443(3): 980-6. PubMed Abstract | Publisher Full Text

85. Monticelli S, Ansel KM, Xiao C, et al.: MicroRNA profiling of the murine hematopoietic system. Genome Biol. 2005; 6(8): R71. PubMed Abstract | Publisher Full Text | Free Full Text

86. Teng $\mathrm{Y}$, Zhang R, Yu H, et al.: Altered MicroRNA Expression Profiles in Activated Mast Cells Following IgE-FceRI Cross-Linking with Antigen. Cell Physiol Biochem. 2015; 35(6): 2098-110. PubMed Abstract | Publisher Full Text

87. Biethahn $\mathrm{K}$, Orinska Z, Vigorito $\mathrm{E}$, et al:: miRNA-155 controls mast cell activation by regulating the PI3K $\gamma$ pathway and anaphylaxis in a mouse model. Allergy. 2014; 69(6): 752-62.

PubMed Abstract | Publisher Full Text

88. F Abebayehu D, Spence AJ, Qayum AA, et al:: Lactic Acid Suppresses IL-33Mediated Mast Cell Inflammatory Responses via Hypoxia-Inducible Factor-1aDependent miR-155 Suppression. J Immunol. 2016; 197(7): 2909-17. PubMed Abstract | Publisher Full Text | Free Full Text | F1000 Recommendation

89. Wang Z, Yi T, Long M, et al.: Involvement of the Negative Feedback of IL-33 Signaling in the Anti-Inflammatory Effect of Electro-acupuncture on Allergic Contact Dermatitis via Targeting MicroRNA-155 in Mast Cells. Inflammation. 2018; 41(3): 859-69.

PubMed Abstract | Publisher Full Text

90. Qayum AA, Paranjape A, Abebayehu D, et al.: IL-10-Induced miR-155 Targets SOCS1 To Enhance IgE-Mediated Mast Cell Function. J Immunol. 2016; 196(11): 4457-67.

PubMed Abstract | Publisher Full Text | Free Full Text

91. $\quad \mathrm{F}$ Li Y, Liu J, Zhang J, et al.: Characterization of microRNA profile in IgE-mediated mouse BMMCs degranulation. J Microbiol Immunol Infect. 2018; pii: S1684-1182(18)30477-8 PubMed Abstract | Publisher Full Text | F1000 Recommendation

92. $\mathrm{F}$ Bao $\mathrm{Y}$, Wang S, Gao Y, et al.: MicroRNA-126 accelerates IgE-mediated mast cell degranulation associated with the PI3K/Akt signaling pathway by promoting $\mathrm{Ca}^{2+}$ influx. Exp Ther Med. 2018; 16(3): 2763-2769. PubMed Abstract | Publisher Full Text | Free Full Text | F1000 Recommendation

93. Yang $\mathrm{Q}, \mathrm{Xu} \mathrm{H}, \mathrm{Yang} \mathrm{J}$, et al:: MicroRNA-223 affects IL-6 secretion in mast cells via the IGF1R/PI3K signaling pathway. Int J Mol Med. 2016; 38(2): 507-12. PubMed Abstract | Publisher Full Tex

94. F Just J, Munk Ipsen P, Kruhøffer M, et al.: Human Mast Cell Sensitization with IgE Increases miRNA-210 Expression. Int Arch Allergy Immunol. 2019; 179(2): 102-7. PubMed Abstract | Publisher Full Text | F1000 Recommendation

95. Li W, Liu F, Wang J, et al.: MicroRNA-21-Mediated Inhibition of Mast Cell Degranulation Involved in the Protective Effect of Berberine on 2,4-Dinitrofluorobenzene-Induced Allergic Contact Dermatitis in Rats via p38 Pathway. Inflammation. 2018; 41(2): 689-99. via p38 Pathway. Inflammation. 2018; 41 (
PubMed Abstract | Publisher Full Text

96. Mayoral RJ, Deho L, Rusca N, et al.: MiR-221 influences effector functions and 
actin cytoskeleton in mast cells. PLoS One. 2011; 6(10): e26133. PubMed Abstract | Publisher Full Text | Free Full Text

97. Mayoral RJ, Pipkin ME, Pachkov M, et al:: MicroRNA-221-222 regulate the cell cycle in mast cells. $J$ Immunol. 2008; 182(1): 433-45. PubMed Abstract | Publisher Full Text | Free Full Text

98. Zhou $\mathrm{Y}$, Yang $\mathrm{Q}, \mathrm{Xu} \mathrm{H}$, et al:: miRNA-221-3p Enhances the Secretion of Interleukin-4 in Mast Cells through the Phosphatase and Tensin Homolog/p38 Nuclear Factor-kappaB Pathway. PLoS One. 2016; 11(2): e0148821. PubMed Abstract | Publisher Full Text | Free Full Text

99. $\mathrm{F}$ Xiao $\mathrm{L}$, Jiang $\mathrm{L}, \mathrm{Hu} \mathrm{Q}$, et al:: MiR-302e attenuates allergic inflammation in vitro model by targeting RelA. Biosci Rep. 2018; 38(3): pii: BSR20180025. PubMed Abstract | Publisher Full Text | Free Full Text | F1000 Recommendation

100. Rusca N, Dehò L, Montagner S, et al:: MiR-146a and NF-кB1 regulate mast cell survival and T lymphocyte differentiation. Mol Cell Biol. 2012; 32(21): 4432-44. PubMed Abstract | Publisher Full Text | Free Full Text

101. Taganov KD, Boldin MP, Chang KJ, et al.: NF-kappaB-dependent induction of microRNA miR-146, an inhibitor targeted to signaling proteins of innate immune responses. Proc Natl Acad Sci U S A. 2006; 103(33): 12481-6. PubMed Abstract | Publisher Full Text | Free Full Text

102. Yang L, Boldin MP, Yu Y, et al:: miR-146a controls the resolution of $\mathrm{T}$ cell responses in mice. J Exp Med. 2012; 209(9): 1655-70. PubMed Abstract | Publisher Full Text | Free Full Text

103. Yu S, Zhang R, Zhu C, et al:: MicroRNA-143 downregulates interleukin-13 receptor alpha1 in human mast cells. Int J Mol Sci. 2013; 14(8): 16958-69. PubMed Abstract | Publisher Full Text | Free Full Text

104. F Lu Y, Li Z, Xie B, et al:: hsa-miR-20a-5p attenuates allergic inflammation in HMC-1 cells by targeting HDAC4. Mol Immunol. 2019; 107: 84-90. PubMed Abstract | Publisher Full Text | F1000 Recommendation

105. Shefler I, Pasmanik-Chor M, Kidron D, et al:: T cell-derived microvesicles induce mast cell production of IL-24: relevance to inflammatory skin diseases. J Allergy Clin Immunol. 2014; 133(1): 217-224.e3-3. PubMed Abstract | Publisher Full Text

106. Shefler I, Salamon $\mathrm{P}$, Reshef $\mathrm{T}$, et al:: $\mathrm{T}$ cell-induced mast cell activation: a role for microparticles released from activated T cells. J Immunol. 2010; 185(7): 4206-12.

PubMed Abstract | Publisher Full Text

107. Baram D, Vaday GG, Salamon $P$, et al.: Human mast cells release metalloproteinase- 9 on contact with activated T cells: juxtacrine regulation by TNF-alpha. J Immunol. 2001; 167(7): 4008-16. PubMed Abstract | Publisher Full Text

108. Mor A, Shefler I, Salamon $P$, et al.: Characterization of ERK activation in human mast cells stimulated by contact with T cells. Inflammation. 2010; 33(2): 119-25. PubMed Abstract | Publisher Full Text

109. Salamon $P$, Shoham NG, Puxeddu I, et al.: Human mast cells release oncostatin $M$ on contact with activated T cells: possible biologic relevance. J Allergy Clin Immunol. 2008; 121(2): 448-455.e5. PubMed Abstract | Publisher Full Tex

110. Shefler I, Mekori YA, Mor A: Stimulation of human mast cells by activated T cells leads to $\mathrm{N}$-Ras activation through Ras guanine nucleotide releasing protein 1. J Allergy Clin Immunol. 2008; 122(6): 1222-5. PubMed Abstract | Publisher Full Text

111. F Shefler I, Salamon $P$, Levi-Schaffer $F$, et al.: MicroRNA-4443 regulates mast cell activation by T cell-derived microvesicles. J Allergy Clin Immunol. 2018; 141(6): 2132-2141.e4. PubMed Abstract | Publisher Full Text | F1000 Recommendation

112. Fenger JM, Bear MD, Volinia S, et al:: Overexpression of miR-9 in mast cells is associated with invasive behavior and spontaneous metastasis. BMC Cancer.
2014; $14: 84$

PubMed Abstract | Publisher Full Text | Free Full Text

113. Noh $\mathrm{K}, \mathrm{Kim} \mathrm{M}, \mathrm{Kim} \mathrm{Y}$, et al.: miR-122-SOCS1-JAK2 axis regulates allergic inflammation and allergic inflammation-promoted cellular interactions. Oncotarget. 2017; 8(38): 63155-63176.

PubMed Abstract | Publisher Full Text | Free Full Text

114. Xiong L, Zhen $S, Y u$ Q et al:: HCV-E2 inhibits hepatocellular carcinoma metastasis by stimulating mast cells to secrete exosomal shuttle microRNAs. Oncol Lett. 2017; 14(2): 2141-2146.

PubMed Abstract | Publisher Full Text | Free Full Text

115. Kawakami T, Blank U: From IgE to Omalizumab. J Immunol. 2016; 197(11): 4187-4192.

PubMed Abstract | Publisher Full Text | Free Full Text

116. Holgate ST, Chuchalin AG, Hébert J, et al.: Efficacy and safety of a recombinan anti-immunoglobulin $\mathrm{E}$ antibody (omalizumab) in severe allergic asthma. Clin Exp Allergy. 2004; 34(4): 632-8.

PubMed Abstract | Publisher Full Text

117. $\mathrm{F}$ Maurer M, Rosén $\mathrm{K}, \mathrm{Hsieh} \mathrm{HJ}$, et al:: Omalizumab for the treatment of chronic idiopathic or spontaneous urticaria. N Engl J Med. 2013; 368(10): 924-35.

PubMed Abstract | Publisher Full Text | F1000 Recommendation

118. F Simpson EL, Bieber T, Guttman-Yassky E, et al:: Two Phase 3 Trials of Dupilumab versus Placebo in Atopic Dermatitis. N Engl J Med. 2016; 375(24): 2335-48.

PubMed Abstract | Publisher Full Text | F1000 Recommendation

119. F Castro M, Corren J, Pavord ID, et al:: Dupilumab Efficacy and Safety in Moderate-to-Severe Uncontrolled Asthma. N Engl J Med. 2018; 378(26): 2486-96. PubMed Abstract | Publisher Full Text | F1000 Recommendation

120. F Rabe KF, Nair P, Brusselle G, et al:: Efficacy and Safety of Dupilumab in Glucocorticoid-Dependent Severe Asthma. N Engl J Med. 2018; 378(26): 2475-85. PubMed Abstract | Publisher Full Text | F1000 Recommendation

121. F Frossi B, De Carli M, Calabrò A: Coeliac Disease and Mast Cells. Int J Mol Sci. 2019; 20(14): pii: E3400.

PubMed Abstract | Publisher Full Text | Free Full Text | F1000 Recommendation

122. Theoharides TC, Valent $P$, Akin $C$, et al:: Mast Cells, Mastocytosis, and Related Disorders. N Engl J Med. 2015; 373(19): 1885-6. PubMed Abstract | Publisher Full Text

123. F Kovanen PT: Mast Cells as Potential Accelerators of Human Atherosclerosis-From Early to Late Lesions. Int J Mol Sci. 2019; 20(18): pii: E4479. PubMed Abstract | Publisher Full Text | Free Full Text | F1000 Recommendation

124. Derakhshani A, Vahidian F, Alihasanzadeh M, et al.: Mast cells: A double-edged sword in cancer. Immunol Lett. 2019; 209: 28-35. PubMed Abstract | Publisher Full Text

125. F Hayashi T, Fujita K, Matsushita M, et al:: Main Inflammatory Cells and Potentials of Anti-Inflammatory Agents in Prostate Cancer. Cancers (Basel). 2019; 11(8): pii: E1153.

PubMed Abstract | Publisher Full Text | Free Full Text | F1000 Recommendation

126. F Traina G: Mast Cells in Gut and Brain and Their Potential Role as an Emerging Therapeutic Target for Neural Diseases. Front Cell Neurosci. 2019; 13: 345.

PubMed Abstract | Publisher Full Text | Free Full Text | F1000 Recommendation

127. Theoharides TC, Tsilioni I, Patel AB, et al: : Atopic diseases and inflammation of the brain in the pathogenesis of autism spectrum disorders. Transl Psychiatry. 2016; 6(6): e844.

PubMed Abstract | Publisher Full Text | Free Full Text 


\section{Open Peer Review}

\section{Current Peer Review Status:}

\section{Editorial Note on the Review Process}

Faculty Reviews are review articles written by the prestigious Members of Faculty Opinions. The articles are commissioned and peer reviewed before publication to ensure that the final, published version is comprehensive and accessible. The reviewers who approved the final version are listed with their names and affiliations.

\section{The reviewers who approved this article are:}

\section{Version 1}

\section{Cem Akin}

Division of Allergy and Clinical Immunology, University of Michigan, Ann Arbor, MI, USA

Competing Interests: Cem Akin has a consultancy agreement with Blueprint Medicines from which he receives research funding.

\section{Jiro Kitaura}

Atopy Research Center, Juntendo University, Tokyo, Japan

Competing Interests: No competing interests were disclosed.

The benefits of publishing with F1000Research:

- Your article is published within days, with no editorial bias

- You can publish traditional articles, null/negative results, case reports, data notes and more

- The peer review process is transparent and collaborative

- Your article is indexed in PubMed after passing peer review

- Dedicated customer support at every stage

For pre-submission enquiries, contact research@f1000.com 